\title{
Estimating HIV Management and Comorbidity Costs Among Aging HIV Patients in the United States: A Systematic Review
}

\author{
Thomas Ward, MMath; Daniel Sugrue, PhD; Olivia Hayward, PhD; Phil McEwan, PhD; \\ Sarah-Jane Anderson, PhD; Sara Lopes, MSc; Yogesh Punekar, PhD; and Alan Oglesby, MPH
}

\begin{abstract}
BACKGROUND: As life expectancy of patients infected with human immunodeficiency virus (HIV) approaches that of the general population, the composition of HIV management costs is likely to change.

OBJECTIVES: To (a) review treatment and disease management costs in HIV, including costs of adverse events (AEs) related to antiretroviral therapy (ART) and long-term toxicities, and (b) explore the evolving cost drivers.

METHODS: A targeted literature review between January 2012 and November 2017 was conducted using PubMed and major conferences. Articles reporting U.S. costs of HIV management, acquired immunodeficiency syndrome (AIDS)-defining events, end of life care, and ART-associated comorbidities such as cardiovascular disease (CVD), chronic kidney disease (CKD), and osteoporosis were included. All costs were inflated to 2017 U.S. dollars. A Markov model-based analysis was conducted to estimate the effect of increased life expectancy on costs associated with HIV treatment and management.
\end{abstract}

RESULTS: 22 studies describing HIV costs in the United States were identified, comprising 16 cost-effectiveness analysis studies, 5 retrospective analyses of health care utilization, and 1 cost analysis in a resource-limited setting. Management costs per patient per month, including routine care costs (on/off ART), non-HIV medication, opportunistic infection prophylaxis, inpatient utilization, outpatient utilization, and emergency department utilization were reported as CD4+ cell-based health state costs ranging from $\$ 1,192$ for patients with CD4 $>500$ cells $/ \mathrm{mm}^{3}$ to $\$ 2,873$ for patients with $\mathrm{CD} 4<50$ cells $/ \mathrm{mm}^{3}$. Event costs for AEs ranged from $\$ 0$ for headache, pain, vomiting, and lipodystrophy to $\$ 31,545$ for myocardial infarction. The mean monthly per-patient costs for CVD management, CKD management, and osteoporosis were $\$ 5,898, \$ 6,108$, and $\$ 4,365$, respectively. Improvements in life expectancy, approaching that of the general population in 2018, are projected to increase ART-related and AE costs by $35.4 \%$ and comorbidity costs by $175.8 \%$ compared with estimated costs with HIV life expectancy observed in 1996.

CONCLUSIONS: This study identified and summarized holistic cost estimates appropriate for use within U.S. HIV cost-effectiveness analyses and demonstrates an increasing contribution of comorbidity outcomes, primarily associated with aging in addition to long-term treatment with ART, not typically evaluated in contemporary HIV cost-effectiveness analyses.

J Manag Care Spec Pharm. 2020;26(2):104-16

Copyright $@ 2020$, Academy of Managed Care Pharmacy. All rights reserved.

\section{What is already known about this subject}

Improvements in antiretroviral therapy (ART) have steadily increased the life expectancy of human immunodeficiency virus (HIV) patients, which is now approaching that of the general population.

Limited data are available on the effect of long-term toxicities and age-related comorbidities on health care costs for patients with HIV in the United States.

As HIV treatment efficacy has improved over the years, more patients are becoming virally suppressed; consequently, HIV patients are estimated to incur lower costs due to HIV management, which includes costs for treatment of acquired immunodeficiency syndrome-defining events.

\section{What this study adds}

The proportion of HIV management costs attributable to ARTassociated long-term toxicities such as cardiovascular disease, chronic kidney disease, and osteoporosis was estimated to increase as patients living with HIV approach life expectancy of the general population.

The overall cost of HIV management has increased over the last few years and is projected to increase further as patients live longer and experience more ART-related comorbidities.

The composition of these costs is also changing, with the cost of ART-related comorbidities, treatment, and adverse events playing a much greater role than before.

$\mathrm{H}$ uman immunodeficiency virus (HIV) causes the progressive deterioration of the immune system through impairment of immune cells such as CD4 lymphocytes, thus making the host more susceptible to infections and other adverse outcomes. ${ }^{1}$ Treatment for HIV infections using antiretroviral therapy (ART) has improved steadily since the advent of potent combination therapy in 1996. With successful treatment, patients can have a life expectancy nearly equivalent to that of the general population.,.$^{2,3}$ Over the past 2 decades, this has resulted in significant reductions in acquired immunodeficiency syndrome (AIDS)-related deaths, thereby transforming HIV infection to a chronic condition. ${ }^{4}$

HIV prevalence in the United States was estimated to include 1.1 million people aged 13 years or over living with 


\section{TABLE 1 Costs Used in Model Inputs}

\begin{tabular}{|c|c|c|c|c|}
\hline \multicolumn{2}{|l|}{ Variable } & $\begin{array}{l}\text { Mean Value } \\
\text { (USD) }\end{array}$ & $\begin{array}{c}\text { Standard } \\
\text { Error (USD) }\end{array}$ & Source \\
\hline \multirow[t]{5}{*}{ Outpatient care } & CD4 $<50$ & 67 & 6.72 & \multirow{35}{*}{ Farnham et al. ${ }^{23}$} \\
\hline & CD4 50-200 & 73 & 7 & \\
\hline & CD4 200-350 & 71 & 7 & \\
\hline & CD4 350-500 & 68 & 7 & \\
\hline & CD4 $>500$ & 66 & 7 & \\
\hline \multirow[t]{5}{*}{ ED visits } & $C D 4<50$ & 117 & 12 & \\
\hline & CD4 50-200 & 53 & 5 & \\
\hline & CD4 200-350 & 30 & 3 & \\
\hline & CD4 350-500 & 23 & 2 & \\
\hline & $\mathrm{CD} 4>500$ & 16 & 2 & \\
\hline \multirow[t]{5}{*}{ Inpatient days } & $\mathrm{CD} 4<50$ & 2,162 & 216 & \\
\hline & CD4 50-200 & 892 & 89 & \\
\hline & CD4 200-350 & 389 & 39 & \\
\hline & CD4 350-500 & 243 & 24 & \\
\hline & $\mathrm{CD} 4>500$ & 191 & 19 & \\
\hline \multirow[t]{5}{*}{ CD4+ cell count test } & $\mathrm{CD} 4<50$ & 18 & 2 & \\
\hline & CD4 50-200 & 18 & 2 & \\
\hline & CD4 200-350 & 18 & 2 & \\
\hline & CD4 350-500 & 18 & 2 & \\
\hline & CD4>500 & 18 & 2 & \\
\hline \multirow[t]{5}{*}{ HIV-1 RNA test } & $\mathrm{CD} 4<50$ & 42 & 4 & \\
\hline & CD4 50-200 & 42 & 4 & \\
\hline & CD4 200-350 & 42 & 4 & \\
\hline & CD4 350-500 & 42 & 4 & \\
\hline & $\mathrm{CD} 4>500$ & 42 & 4 & \\
\hline \multirow[t]{5}{*}{ OI prophylaxis } & $\mathrm{CD} 4<50$ & 107 & 11 & \\
\hline & CD4 50-200 & 68 & 7 & \\
\hline & CD4 200-350 & 28 & 3 & \\
\hline & CD4 350-500 & 17 & 2 & \\
\hline & CD4>500 & 11 & 1 & \\
\hline \multirow{5}{*}{ Non-HIV medication } & $\mathrm{CD} 4<50$ & 238 & 24 & \\
\hline & CD4 50-200 & 230 & 23 & \\
\hline & CD4 200-350 & 213 & 21 & \\
\hline & CD4 350-500 & 217 & 22 & \\
\hline & $\mathrm{CD} 4>500$ & 242 & 24 & \\
\hline
\end{tabular}

HIV (PLHIV) in 2015, of whom 162,500 were undiagnosed patients. ${ }^{5}$ The incidence of new HIV diagnoses in the United States is steady, with 38,739 new patients diagnosed in 2017. ${ }^{5}$ With the advent of newer, more potent ARTs, the life expectancy of patients living with HIV has substantially improved, and by 2020, an estimated 70\% of PLHIV in the United States are projected to be aged 50 years and above. ${ }^{6,7}$ HIV requires life-long treatment, and chronic use of ART has been shown to significantly increase the risk of fractures and osteoporosis, renal and metabolic disorders, central nervous system (CNS) disorders, cardiovascular disease (CVD), and liver disease. ${ }^{8}$ These long-term ART toxicities, coupled with comorbidities, which are more prevalent in PLHIV, have the potential to substantially increase health care resource utilization and costs associated with HIV management.
Historically, U.S. health economic analyses in HIV have focused on the costs associated with HIV treatment and management, costs of AIDS-defining events, and to a lesser extent, HIV prevention costs. ${ }^{9-16}$ However, considering the increasing prevalence of ART-related long-term toxicities and age-related HIV comorbidities, an assessment of their impact on health care costs is warranted. The objective of this study was to review costs associated with HIV management, with particular focus on ART-related long-term toxicities, including CVD, chronic kidney disease (CKD), and osteoporosis. A secondary objective was to subsequently highlight and quantify the evolving cost drivers associated with HIV management through an economic modeling analysis. 


\section{TABLE 1 Costs Used in Model Inputs (continued)}

\section{Variable}

AE treatment costs

CVD costs

\section{Costs of death: End of life care cost}

Individual AIDS-defining event costs
Diarrhea (grade 3/4)

Nausea (grade 3/4)

Vomiting (grade 3/4)

Rash/injection site reaction (grade 3)

Nightmares/abnormal dreams (grade $3 / 4$ )

Dizziness (grade $3 / 4$ )

Depression (grade $3 / 4$ )

Insomnia (grade $3 / 4$ )

Initial cost associated with CVD event

Additional monthly costs applied in each subsequent month (last 3 months)

Acute viral OI-related costs

Acute bacterial OI-related costs

Acute fungal OI-related costs

Acute protozoal OI-related costs

Other OI-related costs

Long-term toxicity: Cost
associated with fracture
Long-term toxicity: Cost
associated with CKD

\begin{tabular}{|c|c|c|c|}
\hline Forearm & 1,979 & 198 & Burge et al. ${ }^{24}$ \\
\hline Shoulder & 1,979 & 198 & Assumption \\
\hline Hip & 59,702 & 5,970 & \multirow{2}{*}{ Burge et al. ${ }^{24}$} \\
\hline Spine & 2,889 & 289 & \\
\hline Stage 1 & 0 & 0 & Assumption \\
\hline Stage 2 & 0 & 0 & Assumption \\
\hline Stage 3 & 3,056 & 306 & Smit et al. ${ }^{26}$ \\
\hline Stage 4 & 3,056 & 306 & Smit et al. ${ }^{26}$ \\
\hline Stage 5 & 3,056 & 306 & Smit et al. ${ }^{26}$ \\
\hline
\end{tabular}

$A E=$ adverse event; $A I D S=$ acquired immunodeficiency syndrome; $C K D=$ chronic kidney disease; $C V D=$ cardiovascular disease; $E D=$ emergency department; HIV $=$ human immunodeficiency syndrome; $\mathrm{OI}=$ opportunistic infection; USD =U.S. dollars

\section{Methods}

\section{Literature Review}

A targeted literature review was conducted to identify estimates of U.S. costs of HIV management. The review was designed according to the Preferred Reporting Items for Systematic review and Meta-Analysis Protocols (PRISMA-P) checklist. ${ }^{17}$ The search strategy used to identify articles is displayed in Appendix A (available in online article). PubMed searches were conducted from January 2012 to November 2017. In addition, 4 conference abstract databases comprising the International Society for Pharmacoeconomics and Outcomes Research (U.S. and European), ID Week contributors (Infectious Diseases Society of America, Society for Healthcare Epidemiology of America, HIV Medicine Association, and Pediatric Infectious Disease Society), and International Aids Society were searched for studies published over the last 5 years.

Titles and abstracts identified by the search strategy were selected based on eligibility criteria. Studies in adult PLHIV reporting costs of HIV management, in particular CD4+ or viral load-based health states, adverse events (AEs), AIDSdefining events, and end of life care, were included. Studies reporting costs of common long-term ART toxicities such as
CVD, CKD, and osteoporosis, including fractures, were also included. The inclusion criteria restricted studies to cost of illness studies or economic evaluations published in the English language. The costs associated with HIV testing, AEs, comorbidities, and HIV management were extracted and inflated to 2017 U.S. dollars using the U.S. Bureau of Labor Statistics Consumer Price Index before reporting in this study. ${ }^{18}$ Where mean costs are presented, a simple mean across endpoints was utilized (i.e., means were not weighted).

\section{Modeling}

A modeling analysis was undertaken to estimate the impact of increased life expectancy among PLHIV on costs associated with HIV treatment and management. A previously presented and validated economic model was used. ${ }^{19-22}$ Model inputs were derived from U.S.-focused publications where possible, and U.S.-specific costs identified by the literature review were used (Table 1). Our model used published values of CD4 health state costs and AIDS-defining events estimated using simulation techniques by Farnham et al. (2013) to predict HIV-related events and associated costs over patient lifetimes. ${ }^{23}$ Costs related to fractures were estimated from a study by Burge et al. 


\section{TABLE 2 Summary of Modeling Studies for CEAs or Economic Evaluations}

\section{Author}

Modeling studies

Bayoumi et al. ${ }^{36}$

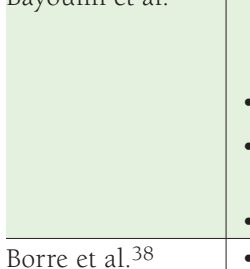

Cost/Resource Description

Cost/Resource Source and Description

- Monthly HIV-related treatment costs, excluding drugs, by CD4 cell count category; and monthly drug costs, excluding ART, by CD4 cell count category

- Serious AE (per event) costs for first and second events

- Monthly HIV-related treatment costs, excluding drugs, by AIDS event incidence

- Monthly drug costs, excluding ART, by AIDS event incidence

- Routine care cost by CD4 cell count category, monthly, off/on ART costs

- Monitoring costs per test: HIV RNA and CD4 cell count

\begin{tabular}{|c|c|}
\hline Cragin et al. ${ }^{39}$ & $\begin{array}{l}\text { - Monthly costs: Post-diagnosis, pre-HAART (physician } \\
\text { counseling, CD4 count test, and viral load test every } 3 \text { months) } \\
\text { - Pre-AIDS on HAART cost } \\
\text { - AIDS cost }\end{array}$ \\
\hline Farnham et al. ${ }^{23}$ & $\begin{array}{l}\text { - Health care utilization costs by CD4 cell count category (quar- } \\
\text { terly): Non-HIV medication, OI prophylaxis, inpatient utiliza- } \\
\text { tion, outpatient utilization, ED utilization } \\
\text { - Cost of AIDS-defining event (per event): PCP, MAC, toxoplas- } \\
\text { mosis, CMV, fungal infection, other } \\
\text { - Disease monitoring costs: CD4 count test (applied quarterly), } \\
\text { HIV RNA viral load testing (applied quarterly), HIV genotype } \\
\text { testing (applied at initiation of each ART) } \\
\text { - Other: Non-HIV medication costs only (applied to individuals } \\
\text { not in care; mean for all CD4 cell counts), program cost per } \\
\text { positive HIV test (ED scenario) }\end{array}$ \\
\hline Girouard et al. 37 & $\begin{array}{l}\text { - Routine care by CD4 category (annual cost) } \\
\text { - Disease monitoring costs (assumed per event): CD4 cell test, } \\
\text { HIV RNA test }\end{array}$ \\
\hline $\begin{array}{l}\text { Hutchinson } \\
\text { et al. } 40\end{array}$ & $\begin{array}{l}\text { - HIV testing costs (annual, per patient), fourth generation: Assay, } \\
\text { test kit costs, labor costs, specimen collection, pretest informa- } \\
\text { tion, Western blot, labor, controls, total test cost } \\
\text { - HIV testing costs (annual, per patient), rapid: Assay, test kit costs } \\
\text { - HIV testing-related labor costs: Specimen collection, pretest } \\
\text { information, Western blot, labor, controls, total test cost } \\
\text { - Tests: CD4 count, viral load test, resistance testing, outpatient } \\
\text { costs }\end{array}$ \\
\hline Juusola et al. ${ }^{47}$ & $\begin{array}{l}\text { - Annual HIV-related health care costs, mean (range): Acute HIV, } \\
\text { asymptomatic HIV (untreated), symptomatic HIV (untreated), } \\
\text { symptomatic HIV (treated with ART) (excludes ART costs) } \\
\text { - Cost of AIDS: Untreated, treated with ART (excludes ART costs) } \\
\text { - Annual non-HIV-related health care costs for uninfected and } \\
\text { infected individuals } \\
\text { - Cost of HIV antibody testing: Uninfected, HIV-infected }\end{array}$ \\
\hline Morris et al. ${ }^{35}$ & $\begin{array}{l}\text { - Routine care (by CD4, monthly) on ART } \\
\text { - AIDS-defining events (cost per infection): Pneumocystis jirovecii } \\
\text { pneumonia, MAC, toxoplasmosis, CMV, fungal infections, other OIs } \\
\text { - End of life care: Chronic AIDS, any other event } \\
\text { - Other costs: CD4 test, HIV RNA test }\end{array}$ \\
\hline
\end{tabular}

The majority of parameters were estimated from the OPTIMA trial (Holodniy et al.) 53 and the Department of Veterans Affairs; Barnett et al. (Department of Veterans Affairs) 61

Unit costs: U.S. Veterans Health Administration

Inpatient costs: Regression method

Outpatient costs: Medicare

Gebo et al. ${ }^{62}$ and Bozzette et al.63

Monitoring costs: CMS67

Costs estimated based on average price for monthly supply of medication and dosage with dispensing/administration fees from a national retail pharmacy, a university-based hospital participating in a buying consortium, and a federal distributor (Bozzette et al.)

Schackman et al.15

Average cost per inpatient day: Derived from the University Health System Consortium database of costs for academic medical centers and affiliated community hospitals in the U.S. (Schackman et al. ${ }^{15}$ )

\section{Gebo et al. ${ }^{64}$}

Cost calculations were performed from the perspective of a largescale purchaser of services. Expenditures were estimated by multiplying utilization data for inpatient days, outpatient visits, ED visits, and lab tests by a unit cost. Data on charges and cost-to-charge ratios for HIV-related inpatient admissions from the Healthcare Expenditure and Utilization Project State Input Databases were used to estimate unit cost/inpatient day (Gebo et al. ${ }^{54}$ )

Estimated unit cost for outpatient visit: 2006 Medicare payment for outpatient visit involving complex evaluation and management

\section{Walensky et al. ${ }^{46}$ who, in turn, sourced costs from Gebo et al. ${ }^{64}$}

Costs from CMS, Clinical Diagnostic Laboratory Fee Schedule

The HIV Detection and Transmission mathematical model 46

Lifetime costs based on Farnham et al. ${ }^{23}$ and Schackman et al. ${ }^{42}$ which sourced costs from Gebo et al. ${ }^{64}$

Dynamic compartmental model of HIV transmission and progression ${ }^{47}$ utilizing HIV cost study values: Long et al. ${ }^{65}$ and Bozette et al. 63

Annual HIV-related costs: Juusola et al., ${ }^{47}$ Vergis et al., 68 Schacke et al., ${ }^{69}$ Daar et al., ${ }^{70}$ Long et al., ${ }^{71}$ Bozette et al., ${ }^{14}$ Schackman et al., ${ }^{15}$ Barnett et al. ${ }^{61}$

Cost of AIDS: Long et al., ${ }^{71}$ Bozzette et al., ${ }^{14}$ Schackman et al., ${ }^{15}$ Barnett et al., ${ }^{61}$ Gebo et al., ${ }^{12}$ Hutchinson et al., ${ }^{72}$ Sanders et al. ${ }^{73}$ HIV testing: CMS67

Routine care, acute OI events, end of life care: Gebo et al.62, Schackman et al. ${ }^{15}$, University Health System Consortium. ${ }^{74}$ Other costs: CMS67 


\section{TABLE 2 Summary of Modeling Studies for CEAs or Economic Evaluations (continued)}

\begin{tabular}{|c|c|c|}
\hline Author & Cost/Resource Description & Cost/Resource Source and Description \\
\hline Peng et al. ${ }^{41}$ & $\begin{array}{l}\text { - AIDS-defining events, acute AIDS-related events (per event): } \\
\text { Cervical cancer, cryptosporidiosis, coccidiosis, oral esophageal } \\
\text { candidiasis, histoplasmosis, PCP, pneumonia, salmonella sepsis, } \\
\text { tuberculosis } \\
\text { - Chronic AIDS-related events (annual): AIDS dementia, CMV } \\
\text { retinitis, CMV colitis/other, cryptococcal meningitis, Kaposi's } \\
\text { sarcoma cutaneous, Kaposi's sarcoma visceral, lymphoma (cen- } \\
\text { tral nervous system), lymphoma (other), MAC, PML, toxoplas- } \\
\text { mic encephalitis, wasting syndrome } \\
\text { - CVD cost per episode } \\
\text { - Other costs: Disease monitoring long-term follow-up costs } \\
\text { (incurred every } 3 \text { months), non-AIDS-related cancer (annual), } \\
\text { non-AIDS-related infection (per episode) }\end{array}$ & $\begin{array}{l}\text { Disease monitoring, AIDS-defining events, chronic AIDS-related } \\
\text { events, other costs: Simpson et al. } .^{34} \text { who derived AIDS-defining } \\
\text { events from event data for South Carolina Medicaid patients from } \\
\text { 2002-200375 } \\
\text { CVD: } 2007 \text { and } 2008 \text { HCUP state inpatient data from State } \\
\text { Inpatient Databases } 76\end{array}$ \\
\hline $\begin{array}{l}\text { Schackman } \\
\text { et al. } 43\end{array}$ & - Cost of genotyping for resistance & $\begin{array}{l}\text { Schackman et al., }{ }^{77} \text { which sourced costs from the Clinical } \\
\text { Laboratory Fee Schedule } 2009^{78}\end{array}$ \\
\hline $\begin{array}{l}\text { Schackman } \\
\text { et al. } 42\end{array}$ & $\begin{array}{l}\text { - All-cause health care cost by CD4 for different age groups (esti- } \\
\text { mated mean monthly costs): 18-29 years old, 30-39 years old, } \\
40-49 \text { years old, } 50+\text { years old } \\
\text { - Other costs: Inpatient visit, outpatient visit, ED visit, CD4 test, } \\
\text { HIV RNA test }\end{array}$ & $\begin{array}{l}\text { Gebo et al. } 64 \\
\text { All-cause health care cost, ED visits: Medical expenditure panel } \\
\text { survey }{ }^{79} \text { and Medicare data; HIVRN } \\
\text { Inpatient cost: HCUP SID } 80,81 \\
\text { Outpatient: Medicare National Physician Fee Schedule } 2009 \\
\text { HIV/CD4 test: Medicare and Medicaid }{ }^{82}\end{array}$ \\
\hline $\begin{array}{l}\text { Simpson } \\
\text { et al. }{ }^{34}\end{array}$ & $\begin{array}{l}\text { - AEs; non-serious side effects (per episode): Diarrhea, headache, } \\
\text { nausea, pain, rash, vomiting } \\
\text { - Serious side effects (per episode): Acute hepatitis/liver failure, } \\
\text { acute renal failure, cholelithiasis, intracranial hemorrhage, } \\
\text { nephrolithiasis, pancreatitis, severe rash/toxic epidermal } \\
\text { necrolysis, MI, stroke, lipoatrophy, lipodystrophy } \\
\text { - AIDS-defining events; acute OIs (per episode): Cervical cancer, } \\
\text { cryptosporidiosis, coccidiosis, oral esophageal candidiasis, his- } \\
\text { toplasmosis, PCP, pneumonia, salmonella sepsis, tuberculosis } \\
\text { - Chronic AIDS-related events (per month): AIDS dementia, CMV } \\
\text { retinitis, CMV colitis/other, cryptococcal meningitis, Kaposi's } \\
\text { sarcoma cutaneous, Kaposi's sarcoma visceral, lymphoma (cen- } \\
\text { tral nervous system), lymphoma (other), MAC, PML, toxoplas- } \\
\text { mic encephalitis, wasting syndrome }\end{array}$ & $\begin{array}{l}\text { AEs, serious and non-serious side effects, AIDS-defining events, } \\
\text { chronic AIDS-related events: South Carolina Medicaid data } 2002 \\
\text { and } 2003^{83}\end{array}$ \\
\hline Smit et al. ${ }^{26}$ & $\begin{array}{l}\text { - CVD: Inpatient admissions, outpatient services, prescription } \\
\text { medication (non-ART), total cost (annual) } \\
\text { - CKD: Inpatient admissions, outpatient services, prescription } \\
\text { medication (non-ART), total cost (annual) } \\
\text { - Other HIV costs: Inpatient admissions, outpatient services, } \\
\text { prescription medication (non-ART), ART } \\
\text { - Diabetes: Inpatient admissions, outpatient services, prescription } \\
\text { medication (non-ART), total costs }\end{array}$ & $\begin{array}{l}\text { Adaptation of a Dutch patient-level simulation model to the U.S. } \\
\text { setting } 50 \\
\text { Annual per-capita costs estimated by calculating incremental costs } \\
\text { in HIV-positive patients with the NCDs to costs for matched HIV- } \\
\text { positive patients without the NCD }\end{array}$ \\
\hline Song et al. ${ }^{44}$ & $\begin{array}{l}\text { - Annual HIV-related health care costs: Acute HIV, asymptomatic } \\
\text { HIV (untreated), symptomatic HIV (untreated), symptomatic } \\
\text { HIV (treated with ART; excludes ART cost) }\end{array}$ & $\begin{array}{l}\text { All costs from Gebo et al. }{ }^{64} \text { and Krentz et al. }{ }^{66} \\
\text { Gebo et al64: Expenditures estimated by multiplying utilization } \\
\text { data for inpatient days, outpatient visits, ED visits, and lab tests by } \\
\text { a unit cost } \\
\text { Krentz et al66: ARV and non-ARV drug costs, lab utilization, and } \\
\text { outpatient care costs were derived directly from the SAC phar- } \\
\text { macy, Calgary Laboratory Services, and the SAC costing data- } \\
\text { base. Inpatient costs (i.e., unit service costs) were supplied by the } \\
\text { regional health service providers. The unit costs used are market } \\
\text { values charged to the regional payer (Calgary Health Region). All } \\
\text { costs were obtained directly from the costing agencies, reported in } \\
\text { Canadian dollars, and adjusted for inflation to } 2006\end{array}$ \\
\hline
\end{tabular}




\section{TABLE 2 Summary of Modeling Studies for CEAs or Economic Evaluations (continued)}

\begin{tabular}{|c|c|c|}
\hline Author & Cost/Resource Description & Cost/Resource Source and Description \\
\hline Sweet et al. ${ }^{45}$ & $\begin{array}{l}\text { - All-cause health care costs by CD4 (ART not included, annual): } \\
\text { Inpatient costs/other medical costs } \\
\text { - Other: } \\
\text { o STR: Total costs, medication costs, inpatient costs, other costs } \\
\text { o MTR: Total costs, medication costs, inpatient costs, other costs }\end{array}$ & All costs from Gebo et al. ${ }^{64}$ \\
\hline Walensky et al. ${ }^{46}$ & $\begin{array}{l}\text { - Routine care by CD4 count, annual (excluding ART) } \\
\text { - Per-person costs by CD4: No ART, 3-pill generic ART, branded } \\
\text { ART }\end{array}$ & $\begin{array}{l}\text { Routine care by CD } 4 \text { count: Gebo et al., }{ }^{84} \text { Bamezai et al., } 85 \\
\text { University Health System Consortium } \\
\text { Gebo et al }{ }^{84} \text { : Expenditures estimated by multiplying utilization } \\
\text { data for inpatient days, outpatient visits, ED visits, and lab tests by } \\
\text { a unit cost }{ }^{84}\end{array}$ \\
\hline \multicolumn{3}{|c|}{ Retrospective review of claims data } \\
\hline Ritchwood et al. ${ }^{50}$ & $\begin{array}{l}\text { - Unadjusted means of total costs and breakdown of health care } \\
\text { expenditures: Total, inpatient, office-based, medications, outpa- } \\
\text { tient, ED, home health, dental }\end{array}$ & $\begin{array}{l}\text { All costs from Medical Expenditure Panel Survey-Household } \\
\text { Component for the years 2002-2011 }\end{array}$ \\
\hline Dekoven et al. ${ }^{48}$ & $\begin{array}{l}\text { AEs: } \\
\text { - Depression (all-cause health care costs) } \\
\text { - Diabetes/insulin resistance (all-cause health care costs) } \\
\text { - Diarrhea (all-cause health care costs) } \\
\text { - Dizziness (all-cause health care costs) } \\
\text { - Hepatic disorders (all-cause health care costs) } \\
\text { - Lipid disorders (all-cause health care costs) } \\
\text { - Nausea/vomiting (all-cause health care costs) } \\
\text { - Rash (all-cause health care costs) } \\
\text { - Renal disorders (all-cause health care costs) } \\
\text { - Somnolence/sleep effects (all-cause health care costs) }\end{array}$ & $\begin{array}{l}\text { Data derived from IMS Health's PharMetrics Plus Health Plan } \\
\text { Claims Database } \\
\text { Inpatient costs based on hospitalizations, with ICD-9 diagnosis } \\
\text { code reported } \\
\text { ICD-9 codes were used to calculate outpatient costs (ED visits, GP } \\
\text { visits, lab and pathology claims, radiology, surgery, and ancillary } \\
\text { services) }\end{array}$ \\
\hline
\end{tabular}

continued on next page

(2007) (the underlying study utilized by Gallant et al. [2018]), while CKD and CVD costs were informed by Smit et al. (2017). ${ }^{24-26}$ Costs and benefits were discounted at a rate of 3\% annually.

The model has been described in detail elsewhere. ${ }^{19-22}$ In brief, modeled health states included CD4 cell count-based health states nested within 3 strata of viral load and death. Patients initiated their first treatment (ART 1) in one of the CD4 and viral load states based on their baseline parameters. During each monthly cycle, patients' viral status can improve, decline, or remain constant, driven by treatment-specific efficacy estimates. Four treatment lines are incorporated: 3 defined ART regimens and 1 unspecified salvage therapy line composed of pooled ART regimens. Patients are assumed to be at risk of experiencing treatment failure due to AEs, virologic failure (inability to achieve HIV RNA level $<50$ copies/mL), and viral rebound (HIV RNA $\geq 50$ copies/mL after virologic suppression). Upon discontinuation, patients moved to the next treatment line. In a typical cycle length of 1 month, patients were exposed to risks of treatment-related AEs, AIDS-defining events, CVD events, CKD progression, bone fractures, and death.

\section{Analyses}

The current analysis focused on the potential impact of improving HIV survival on the incidence and costs of CVD, endstage renal disease (ESRD), and fracture incidence. Utilizing published estimates, the model was calibrated to HIV-specific life expectancy predicted at different time points between 1996 and 2008. ${ }^{27}$ Mortality in the cost-effectiveness model is estimated based on country-specific life table estimates adjusted based on relative risks stratified by CD4 cell counts; calibration was undertaken through adjustment of virologic suppression rates for PLHIV, with historic cohorts less likely to remain suppressed. The incidence of CVD was estimated using Framingham risk equations and the incidence of fractures was estimated by the Sheffield FRAX tool. ${ }^{28,29}$ The incidence of CKD stage 5 was defined as an estimated glomerular filtration rate (eGFR) of $<15 \mathrm{~mL} / \mathrm{min} / 1.73 \mathrm{~m}^{2}$. An annual decline in eGFR (mean annual decline: $-1.23 \mathrm{~mL} / \mathrm{min} / 1.73 \mathrm{~m}^{2}$ ) and bone mineral density (mean annual decline: $-0.0029 \mathrm{~g} / \mathrm{cm}^{3}$ ) was applied based on published literature. ${ }^{30,31}$ With the exception of age, all prognostic factors utilized by the Framingham risk equations remained constant over the modeled horizon. 


\section{TABLE 2 Summary of Modeling Studies for CEAs or Economic Evaluations (continued)}

\begin{tabular}{|c|c|c|}
\hline Author & Cost/Resource Description & Cost/Resource Source and Description \\
\hline Gallant et al. ${ }^{25}$ & $\begin{array}{l}\text { CVD, CKD, and fracture per-patient per-month costs: } \\
\text { - Commercial (private payer) (CVD, CKD, and fracture), Medicare } \\
\text { (public payer) (CVD and CKD): } \\
\text { - Inpatient admissions } \\
\text { - Outpatient services } \\
\text { - ED visits (outpatient subset) } \\
\text { - Prescriptions total } \\
\text { - Prescription HIV medications } \\
\text { - Prescription non-HIV medications } \\
\text { - Total health care expenditures } \\
\text { - Incremental health care expenditures } \\
\text { Other costs; CKD + CVD event population, per-patient per-month } \\
\text { costs (case): } \\
\text { - Commercial (private payer) and Medicare (public payer) } \\
\text { - Inpatient admissions } \\
\text { - Outpatient services } \\
\text { - Prescriptions total } \\
\text { - Prescription HIV medications } \\
\text { - Prescription non-HIV medications } \\
\text { - Total health care expenditures }\end{array}$ & $\begin{array}{l}\text { U.S. administrative claims data representing private (commer- } \\
\text { cial) and public (Medicaid) payer segments from the MarketScan } \\
\text { Commercial Claims and Encounters database (commercial) and the } \\
\text { MarketScan Multi-State Medicaid (Medicaid) database }\end{array}$ \\
\hline Korsnes et al. ${ }^{49}$ & $\begin{array}{l}\text { Other costs: } \\
\text { - Mean cost per patient: Inpatient cost, ED cost, prescription cost, } \\
\text { non-pharmacy service }\end{array}$ & $\begin{array}{l}\text { All costs from the MarketScan family of databases: MarketScan } \\
\text { Commercial Claims and Encounters Database and the Medicare } \\
\text { Supplemental and Coordination of Benefits database (commercial) } \\
\text { and state Medicaid programs (MarketScan's Medicaid Multi-State } \\
\text { Database) }\end{array}$ \\
\hline Solem et al. ${ }^{51}$ & $\begin{array}{l}\text { - Other costs by CD4 (unadjusted total costs per patients per } \\
\text { month) }\end{array}$ & $\begin{array}{l}\text { All costs from the MarketScan Commercial Claims and Encounters } \\
\text { Database (2007-2011) and the MarketScan Lab Database (2007- } \\
\text { 2010) }\end{array}$ \\
\hline
\end{tabular}

$A E=$ adverse event; $A I D S=$ acquired immunodeficiency syndrome; $A R T=$ antiretroviral therapy; $C E A=$ cost-effectiveness analysis; $C K D=$ chronic kidney disease; $C M S=$ Centers for Medicare \& Medicaid Services; $C M V=$ cytomegalovirus; $C V D=$ cardiovascular disease; $E D=$ emergency department; HAART=highly active antiretroviral therapy; HCUP = Healthcare Cost and Utilization Project; HIV=human immunodeficiency virus; HIVRN=HIV Research Network; ICD-9=International Classification of Diseases, Ninth Revision; $M A C=$ mycobacterium avium complex; $M I=$ myocardial infarction; $M T R=$ multi-tablet regimen; $N C D=$ noncommunicable disease; OI=opportunistic infection; $P C P=$ pneumocystis pneumonia; $P M L=$ progressive multifocal leukoencephalopathy; $S A C=$ Southern Alberta Cohort; SID = state inpatient database; $S T R=$ single-tablet regimen .

A comparative analysis was performed utilizing 6 hypothetical cohorts, representing the life expectancy of PLHIV at different periods in time, with a baseline age of 20 years modeled over a lifetime. These included patients that do not achieve viral suppression (assumed equivalent to survival prior to the introduction of multiclass combination ART lapproved by the U.S Food and Drug Administration in 1997]; cohort 1); patients with survival rates observed in years 1996, 2000, 2004, and 2008 (cohorts 2-5); and patients achieving a life expectancy equivalent to the general population in the United States in 2018 (cohort 6). ${ }^{32,33}$ The predicted cumulative incidence of CVD; CKD stage 5; and hip, spine, shoulder, and arm fractures and total lifetime HIV-related costs were compared. Analyses were varied probabilistically to reflect the heterogeneity of the population by varying clinical inputs related to CVD, ESRD, and fracture incidence, with all other parameters remaining unchanged.

\section{Results}

The index searches identified 1,347 references resulting in 59 full-text articles. In total, 33 publications that described costs or resource use in the U.S. setting were included in the qualitative synthesis of this study (Appendix B, available in online article). Of these, 5 conference proceedings that did not present the costing year were excluded from the final selection.

Of the 22 full-text publications that fully described costs, 16 studies used an economic model to conduct cost-effectiveness analyses (CEAs) or economic evaluations, 5 were retrospective analyses of health care utilization, and 1 study undertook a cost analysis in a resource-limited setting (Table 2). ${ }^{23,25,26,34-52}$ 


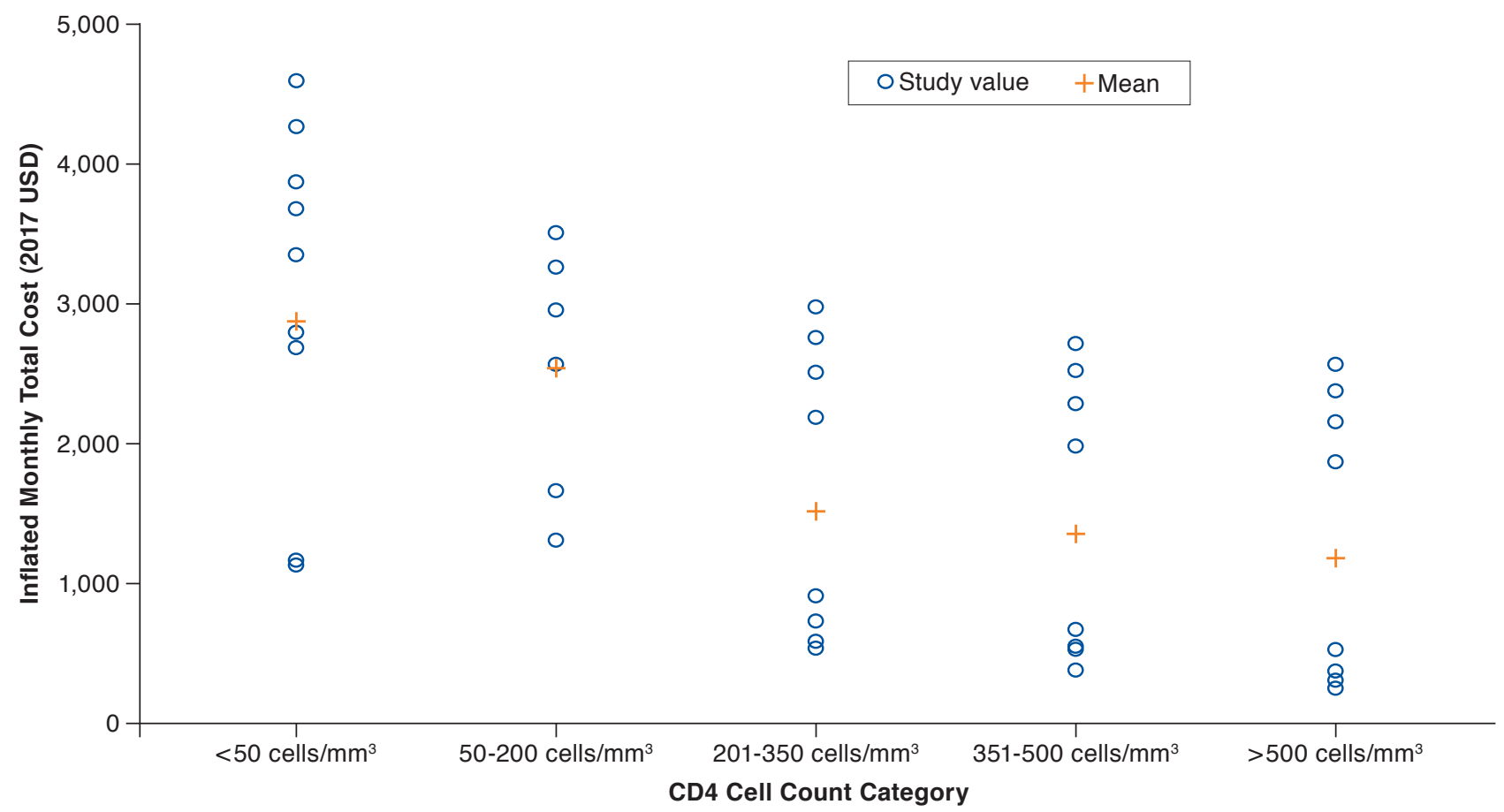

USD = U.S. dollars.

\section{Costs by CD4 Cell Count Categories}

A total of 6 studies reported HIV treatment and disease management costs associated with CD4 cell-based health states. They were presented as annual, quarterly, or monthly costs. ${ }^{23,37,38,42,45,46}$ The total costs ranged from $\$ 254$ to $\$ 6,608$ per month, with lower CD4 cell counts associated with higher costs (Figure 1, presenting CD4 categories used in the model). The mean monthly costs ranged from $\$ 2,873$ for patients with CD4 counts $<50$ cells $/ \mathrm{mm}^{3}$ to $\$ 1,192$ for patients with CD4 counts $>500$ cells $/ \mathrm{mm}^{3}$. Across the most commonly identified CD4 cell categories, and those that were utilized in the model, the average monthly costs were $\$ 2,873$ (range $=\$ 1,136-\$ 4,596$ ), $\$ 2,546$ (range $=\$ 1,317-\$ 3,509), \$ 1,531$ (range $=\$ 536-\$ 2,983$ ), $\$ 1,357$ (range $=\$ 385-\$ 2,721$ ), and $\$ 1,192$ (range $=\$ 254-$ $\$ 2,565)$ for the $<50$ cells $/ \mathrm{mm}^{3}, 50-200$ cells $/ \mathrm{mm}^{3}, 201-350$ cells $/ \mathrm{mm}^{3}, 351-500$ cells $/ \mathrm{mm}^{3}$, and $>500$ cells $/ \mathrm{mm}^{3}$ CD4 cell count categories, respectively. Six studies reported costs of tests to estimate CD4+ counts (mean cost $=\$ 70.07$; range $=\$ 53.36$ $\$ 126.48$ ) and HIV RNA (mean cost $=\$ 104.10$; range $=\$ 69.78$ \$151.63). ${ }^{23,37,38,42,45,46}$ Further, 3 studies estimated costs of HIV genotype testing (mean cost $=\$ 315.59$; range: $\$ 40.03-\$ 535.98$ ) to assess resistance profiles of patients. ${ }^{23,40,42}$

\section{AE and AIDS-Defining Event Costs}

Three studies estimated costs of AEs, reporting them as per-event costs or annual event-related costs (Table 1)..$^{34,36,48}$ Bayoumi et al. (2013) estimated the cost of first and subsequent serious AEs to be $\$ 12,412$ and $\$ 15,930$ using data from the OPTIMA trial in 2017. 36,53 Studies by Simpson et al. (2013) and Dekoven et al. (2016) using U.S. claims databases calculated costs for several AEs ranging from $\$ 0$ for AEs such as headache, pain, vomiting, and lipodystrophy to $\$ 23,964$ for intracranial hemorrhage, $\$ 25,912$ for stroke, and $\$ 31,545$ for myocardial infarction. ${ }^{34,48}$ Costs for the majority of AEs were less than $\$ 5,000$ per event. Four studies estimated costs stratified by types of opportunistic infections (OIs) into bacterial OIs, viral OIs, fungal OIs, protozoal OIs, cancer, and others (Table 1)..$^{23,34,35,41}$ The mean per-event costs for OIs ranged from $\$ 8,495$ for viral OIs to $\$ 13,036$ for protozoal OIs. The overall mean cost per event across all AIDS-defining events was $\$ 10,465$ and the corresponding monthly mean cost was $\$ 4,464$.

\section{Long-Term Toxicity Costs}

Outcomes associated with CVD, CKD, and fractures/osteoporosis were explored as long-term toxicities in HIV-infected patients. Three studies reported the cost of CVD, 2 studies reported the cost of $\mathrm{CKD}$, and a single study reported the cost 


\section{FIGURE 2 Estimated Survival of HIV Patients, Stratified by Year, Compared to the Cumulative Incidence of} CVD, CKD Stage 5, and Bone Fractures Among the Total Cohort

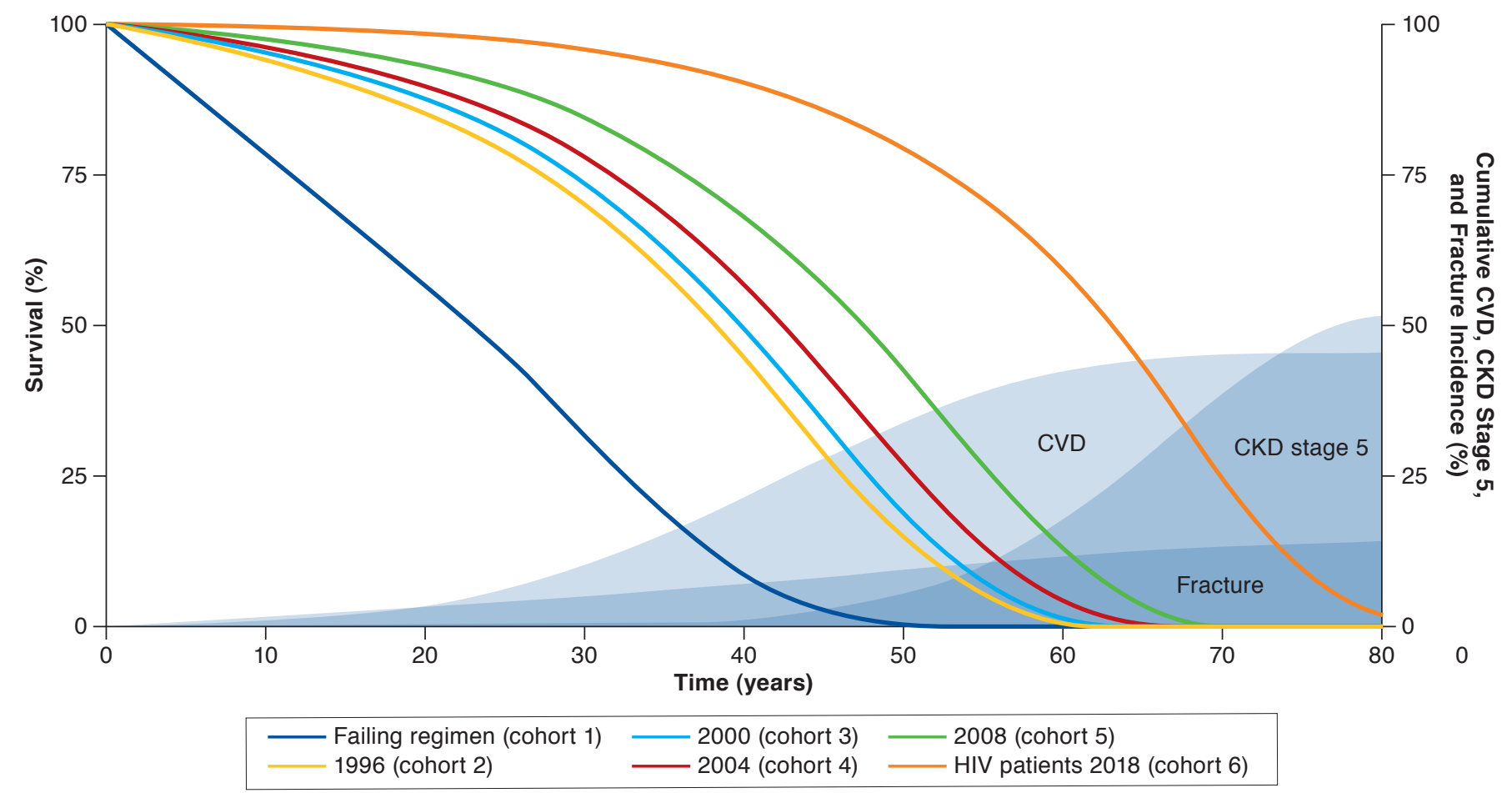

$C K D=$ chronic kidney disease $; C V D=$ cardiovascular disease; $H I V=$ human immunodeficiency virus

of fracture/osteoporosis. ${ }^{25,26,41}$ The study by Peng et al. (2015) reported the total per-event cost of CVD to be $\$ 28,728$, while studies by Smit et al. and Gallant et al. (2018) reported further cost breakdowns with inpatient, outpatient, emergency care, and prescription costs for non-HIV prescriptions (Table 1).25,41 The mean monthly cost of CVD management across all studies was estimated to be $\$ 5,898$ per patient. The costs of CKD and osteoporosis were also further divided into cost components, with average monthly costs of $\$ 6,108$ and $\$ 4,365$, respectively.

\section{Modeling Analyses}

Predicted survival for each of the modeled patient cohorts is presented in Figure 2. In line with published estimates, the model assumed improved survival between 1996 and 2008. Patients failing to achieve viral suppression (cohort 1), who were assumed representative of patients before the widespread use of highly active ART, were estimated to be associated with a life expectancy of 22.4 years. The model estimated life expectancies of 36.2, 37.9, 40.5, and 45.1 years for a typical 20-yearold patient at the time of diagnosis for cohorts $2-5$, respectively.

The incidence of bone fractures remained relatively constant over the modeled horizon, while there was a gradual increase in CVD incidence between 40 and 80 years, after which it plateaued. The incidence of CKD stage 5 remained relatively low until patients reached the age of 75 and increased significantly thereafter. Analysis showed a $33.4 \%$ increase in life expectancy in cohort 6 compared to cohort 5. Such an improvement in survival represented an increase of $71.3 \%$, $58.3 \%$, and $>1,000 \%$ in the incidence of bone fractures, CVD, and CKD stage 5, respectively.

The economic impact associated with the increased incidence of CVD, CKD stage 5, and bone fractures was reflected in the total lifetime cost outcomes predicted by the model (Figure 3). The total HIV lifetime cost per patient was estimated to be $\$ 1,246,810, \$ 1,420,869$, and $\$ 1,673,510$ for cohorts 2,5 , and 6 , respectively. The cost increases were driven by treatment and $\mathrm{AE}$ costs (35.4\% increase between cohort 2 and cohort 6) but also by costs of treatment for comorbidities such as CVD (179.9\% increase) and CKD (174.3\% increase). HIV management costs, including costs of inpatient care, emergency department and outpatient visits, OI prophylaxis, HIV testing, and non-HIV medication, however, decreased as HIV patients approached general population survival rates due to improvements in CD4 cell counts and viral loads. 


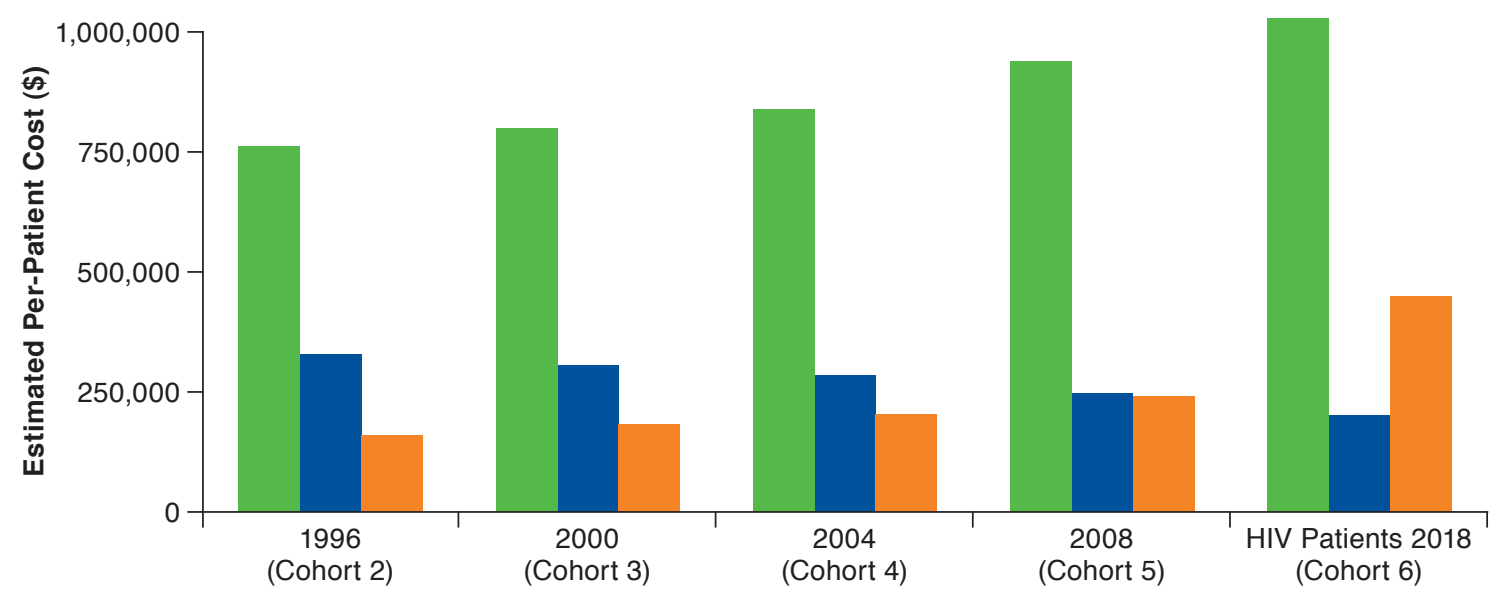

\section{Treatment and $\mathrm{AEs}^{\mathrm{a}}$ \\ Disease management ${ }^{\mathrm{b}}$ Comorbidities ${ }^{c}$}

aTreatment and AEs: treatment costs and treatment of AEs.

bDisease management: outpatient care, emergency department visits, inpatient day, HIV testing, OI prophylaxis, and non-HIV medication.

${ }^{c}$ Comorbidities: CVD, CKD, and fracture risk.

$A E=$ adverse event $; C K D=$ chronic kidney disease $; C V D=$ cardiovascular disease $;$ HIV=human immunodeficiency virus; OI=opportunistic infection.

\section{Discussion}

With the advent of newer, more efficacious ARTs, HIV patients are expected to live longer, with a mean life expectancy approaching that of the general population. ${ }^{6,7}$ This aging population requires chronic care to manage HIV disease progression, and with extension of life comes the likelihood of additional resource-intensive age-related comorbidities, which are not currently a focus of contemporary HIV CEAs. ${ }^{54}$ Long-term ART exposure has the potential to lead to the early onset of such comorbidities due to the impact of certain HIV therapies on long-term toxicity risk factors. ${ }^{55-57}$ As a result, the composition of care needed for HIV patients has evolved over the last 2 decades and is expected to change further in the future.

Our study reviewed published literature on costs of HIV management in the United States and modeled the potential future costs of aging HIV patients. Modeled results estimated that, as the survival of HIV patients approached that of the general population, lifetime HIV costs increased, with the distribution of costs across different contributors varying significantly. HIV treatment and related AE and toxicity costs were estimated to increase as patients received treatment for a longer duration, while HIV management costs showed an estimated decrease, as improved survival is inherently associated with improved viral load and CD4 cell count profiles and associated reductions in AIDS-defining event incidence and virological failure. The most significant estimated changes were the rapid increase in costs of comorbidities associated with aging and long-term use of ART, such as CVD, CKD stage 5, and osteoporosis. As life expectancy improved beyond 50 years, the estimated incidence of these ART- and age-associated comorbidities significantly increased, resulting in their increased contribution to total HIV costs.

This study focused on 3 of the most common ART-specific comorbidities. However, there is evidence to suggest that several other chronic conditions such as depression, diabetes, and respiratory diseases are more prevalent in HIV patients, and their contribution to lifetime HIV costs is likely to increase in aging patients. ${ }^{54}$ Interventions that improve communication and potentially regular contact between patients and health care professionals are likely to lead to early detection and better management of these comorbidities. There is a large amount of literature relating ART to long-term toxicities, some of which are highly prevalent in aging HIV patients. Interventions that reduce the cumulative exposure of antiretrovirals may also help in reducing prevalence of these toxicities. Future research should focus on assessing the impact of reduced antiretroviral exposure on lifetime HIV costs. 
The costs of specific comorbidities identified in our review for HIV patients were higher than those reported in the literature for non-HIV patients. The mean annual cost of CKD stage 5 in our study was $\$ 73,296$. A study by Ozieh et al. (2017) estimated the annual cost of CKD in the U.S. general population to be $\$ 37,649$ in 2010/2011 (inflated to $\$ 44,644$ in 2017), while another study by Honeycutt et al. (2013) estimated the annual cost of stage 4 CKD to be $\$ 12,700$ in 2010 (inflated to $\$ 15,518$ in 2017). ${ }^{58,59}$ Similarly, Weaver et al. (2017) estimated the annual medical and pharmacy costs following an incident fracture to be $\$ 27,844 .{ }^{60}$ The corresponding annual costs in our study, which included medical and prescription costs, were $\$ 52,380$. This suggests an additional cost burden among HIV patients for these comorbidities, which may be due to the effect of long-term treatment with ART. Given the substantial costs associated with such comorbidities, there is real potential for the incidence of such events to significantly affect cost-effectiveness outcomes and, subsequently, reimbursement decisions.

\section{Limitations}

This study has some limitations. First, all HIV- and ARTassociated potential comorbidities were not considered. Second, although systematic literature reviews are the preferred method for sourcing parameters for cost-effectiveness models, our approach was limited to a targeted literature review. We would not anticipate a systematic review to identify much or any additional relevant sources, however, since the evidence base in this specific area is not extensive. Third, those studies captured by this review commonly obtained cost data from one of a number of key cost studies, due to the limited evidence base, which represents a key limitation of this study.

\section{Conclusions}

This study demonstrated that as life expectancy of HIV patients improved, a significantly increased contribution of ART-associated comorbidities, including CKD, CVD, and osteoporosis, is observed. This contrasts with the overall estimated decrease in HIV management costs, likely due to improvements in patients' viral load and CD4 cell counts and subsequent reduced likelihood of experiencing AIDS-defining event incidence and virological failure. Future CEAs should consider the complete range of clinical outcomes for which HIV treatments may have an impact, rather than relying on historical precedent when informing modeled endpoints. Future research should also focus on assessing the effect of reduced antiretroviral exposure on lifetime HIV costs, in addition to how the resultant costs compare to that of a general population.

\section{Authors}

THOMAS WARD, MMath; DANIEL SUGRUE, PhD; OLIVIA HAYWARD, PhD; and PHIL MCEWAN, PhD, HEOR Ltd, Cardiff, United Kingdom. SARAH-JANE ANDERSON, PhD; SARA LOPES, MSc; and YOGESH PUNEKAR, PhD, ViiV Healthcare, Brentford, United Kingdom. ALAN OGLESBY, MPH, ViiV Healthcare, Research Triangle, North Carolina.

AUTHOR CORRESPONDENCE: Olivia Hayward, PhD, HEOR Ltd, Unit A, Cardiff Gate Business Park, Copse Walk, Pontprennau, Cardiff, CF23 8RB, UK. Tel.: +44 2920 399146; E-mail: olivia.hayward@heor.co.uk.

\section{DISCLOSURES}

This analysis was sponsored by ViiV Healthcare, which had no role in the analyses and interpretation of study results. Ward, Sugrue, Hayward, and McEwan are employees of HEOR Ltd, which received funding from ViiV Healthcare to conduct this study. Anderson is an employee of GlaxoSmithKline and holds shares in the company. Punekar and Oglesby are employees of ViiV Healthcare and hold shares in GlaxoSmithKline. Lopes was employed by ViiV Healthcare at the time of the study and holds shares in GlaxoSmithKline.

\section{ACKNOWLEDGMENTS}

Editorial support in the form of development of the draft outline in consultation with the authors, editorial suggestions to draft versions of this manuscript, assembling tables and figures, collating author comments, copyediting, fact checking, referencing, and graphic services was provided by A Prabhavalkar and was funded by ViiV Healthcare.

\section{REFERENCES}

1. World Health Organization. Health topics: HIV/AIDS. 2017. Available at: https://www.afro.who.int/health-topics/hivaids. Accessed January 24, 2020

2. U.S. Department of Health and Human Services. Panel on antiretroviral guidelines for adults and adolescents. Guidelines for the use of antiretroviral agents in adults and adolescents living with HIV. Available at: https://aidsinfo.nih.gov/guidelines. Accessed January 9, 2020.

3. Bhaskaran K, Hamouda O, Sannes M, et al. Changes in the risk of death after HIV seroconversion compared with mortality in the general population. JAMA. 2008;300(1):51-59.

4. Marcus JL, Chao CR, Leyden WA, et al. Narrowing the gap in life expectancy between HIV-infected and HIV-uninfected individuals with access to care. J Acquir Immune Defic Syndr. 2016;73:39-46.

5. Centers for Disease Control and Prevention. Estimated HIV incidence and prevalence in the United States, 2010-2015. HIV Surveillance Supplemental Report. 2018;23(No. 1). March 2018. Available at: https://www.cdc.gov/hiv/ pdf/library/reports/surveillance/cdc-hiv-surveillance-supplemental-reportvol-23-1.pdf. Accessed January 9, 2020.

6. Nakagawa F, Lodwick RK, Smith CJ, et al. Projected life expectancy of people with HIV according to timing of diagnosis. AIDS. 2012;26(3):335-43.

7. Aitcheson P, Brennan-Ing M, Espinoza R, Pacheco B, Tax A, Tietz D. Eight policy recommendations for improving the health and wellness of older adults with HIV. 2014. Available at: https://www.diverseelders.org/resource/ eight-policy-recommendations-for-improving-the-health-wellness-of-olderadults-with-hiv/. Accessed January 9, 2020.

8. Chawla A, Wang C, Patton C, et al. Toxicity of antiretroviral treatment regimens and implications for long-term use. Infect Dis Ther. 2018;7:183. 
9. Hay JW, Osmond DH, Jacobson MA. Projecting the medical costs of AIDS and ARC in the United States. J Acquir Immune Defic Syndr. 1988;1:466-85.

10. Hellinger FJ. The lifetime cost of treating a person with HIV. JAMA. 1993;270:474-78

11. Pinkerton SD, Holtgrave DR. Lifetime costs of HIV/AIDS medical care. J Acquir Immune Defic Syndr Hum Retrovirol. 1997;14:380-82.

12. Gebo KA, Chaisson RE, Folkemer JG, Bartlett JG, Moore RD. Costs of HIV medical care in the era of highly active antiretroviral therapy. AIDS. 1999;13:963-69.

13. Hellinger FJ, Fleishman JA. Estimating the national cost of treating people with HIV disease: patient, payer, and provider data. J Acquir Immune Defic Syndr. 2000;24:182-88.

14. Bozzette SA, Joyce G, McCaffrey DF, et al. Expenditures for the care of HIV-infected patients in the era of highly active antiretroviral therapy. N Engl J Med. 2001;344:817-23.

15. Schackman BR, Gebo KA, Walensky RP, et al. The lifetime cost of current human immunodeficiency virus care in the United States. Med Care. 2006:44:990-97.

16. Farnham PG, Holtgrave DR, Sansom SL, Hall HI. Medical costs averted by HIV prevention efforts in the United States, 1991-2006. J Acquir Immune Defic Syndr. 2010;54:565-67.

17. Moher D, Shamseer L, Clarke M, et al. Preferred reporting items for systematic review and meta-analysis protocols (PRISMA-P) 2015 statement. Syst Rev. 2015;4(1):1.

18. Federal Reserve Bank of St. Louis; U.S. Bureau of Labor Statistics. Consumer Price Index for All Urban Consumers: Medical Care. Available at: https://fred.stlouisfed.org/series/CPIMEDSL. Accessed January 9, 2020.

19. Arthurs E, Ward T, Darlington O, et al. Cost-effectiveness of dolutegravir/ rilpivirine for the treatment of human immunodeficiency virus (HIV-1) infection in virologically-suppressed patients in Canada. Value Health. 2018;21(Suppl 1):9-10.

20. Darlington O, Lopes S, Ward T, et al. Estimating health outcomes in HIV infected patients treated with a dual regimen of dolutegravir and rilpivirine in Europe. Presented at: ISPOR U.S.; May 19-23, 2018; Baltimore, MD.

21. McEwan P, Darlington O, van Doornewaard A, et al. Estimating life years and quality-adjusted life years in heavily treatment-experienced (HTE) patients. Presented at: ISPOR Europe; November 4-8, 2017; Glasgow, Scotland.

22. Ward T, Punekar Y, Darlington O, et al. Dolutegravir plus lamivudine for the treatment of naive adults living with HIV-1: a UK cost-minimization analysis. Presented at: ISPOR Europe; November 10-14, 2018; Barcelona, Spain.

23. Farnham PG, Gopalappa C, Sansom SL, et al. Updates of lifetime costs of care and quality-of-life estimates for HIV-infected persons in the United States: late versus early diagnosis and entry into care. J Acquir Immune Defic Syndr. 2013;64(2):183-89.

24. Burge R, Dawson-Hughes B, Solomon DH, Wong JB, King A, Tosteson A. Incidence and economic burden of osteoporosis-related fractures in the United States, 2005-2025. J Bone Miner Res. 2007;22(3):465-75.

25. Gallant J, Hsue P, Budd D, Mayer N. Healthcare utilization and direct costs of non-infectious comorbidities in HIV-infected patients in the USA. Curr Med Res Opin. 2018;34(1):13-23.

26. Smit M, Cassidy R, Cozzi-Lepri A, et al. Projections of non-communicable disease and health care costs among HIV-positive persons in Italy and the U.S.A.: a modelling study. PLoS One. 2017;12(10):e0186638.

27. The Antiretroviral Therapy Cohort Collaboration. Survival of HIVpositive patients starting antiretroviral therapy between 1996 and 2013: a collaborative analysis of cohort studies. Lancet HIV. 2017;4(8):e349-e56.

28. D'Agostino RB Sr, Vasan RS, Pencina MJ, et al. General cardiovascular risk profile for use in primary care: the Framingham Heart Study. Circulation. 2008;117(6):743-53.
29. Sheffield University. Fracture Risk Assessment Tool. Available at: https:// www.sheffield.ac.uk/FRAX/tool.aspx. Accessed January 9, 2020.

30. Gianotti N, Galli L, Poli A, et al. Estimated glomerular filtration rate trajectories in HIV-infected subjects treated with different ritonavir-boosted protease inhibitors and tenofovir disoproxil fumarate or abacavir. Med (Baltimore). 2016;95(22):e3780.

31. Berger C, Langsetmo L, Joseph L, et al. Change in bone mineral density as a function of age in women and men and association with the use of antiresorptive agents. CMAJ. 2008;178(13):1660-08.

32. Centers for Disease Control and Prevention. United States Life Tables. 2018;66:64. Available at: https://www.cdc.gov/nchs/products/life_tables.htm. Accessed January 9, 2020.

33. U.S. Food and Drug Administration. HIV/AIDS historical time line 19951999. Available at: https://www.fda.gov/forpatients/illness/hivaids/history/ ucm151079.htm. Accessed January 9, 2020.

34. Simpson KN, Pei PP, Moller J, et al. Lopinavir/ritonavir versus darunavir plus ritonavir for HIV infection: a cost-effectiveness analysis for the United States. Pharmacoeconomics. 2013;31(5):427-44.

35. Morris BL, Scott CA, Wilkin TJ, et al. Cost-effectiveness of adding an agent that improves immune responses to initial antiretroviral therapy (ART) in HIV-infected patients: guidance for drug development. HIV Clin Trials. 2012;13(1):1-10.

36. Bayoumi AM, Barnett PG, Joyce VR, et al. Cost-effectiveness of newer antiretroviral drugs in treatment-experienced patients with multi-drug resistant HIV disease. J Acquir Immune Defic Syndr. 2013;64(4):382-91.

37. Girouard MP, Sax PE, Parker RA, et al. The cost-effectiveness and budget impact of 2-drug dolutegravir-lamivudine regimens for the treatment of HIV infection in the United States. Clin Infect Dis. 2016;62(6):784-91.

38. Borre ED, Hyle EP, Paltiel AD, et al. The clinical and economic impact of attaining national HIV/AIDS strategy treatment targets in the United States. J Infect Dis. 2017;216(7):798-807.

39. Cragin L, Pan F, Peng S, et al. Cost-effectiveness of a fourth-generation combination immunoassay for human immunodeficiency virus (HIV) antibody and p24 antigen for the detection of HIV infections in the United States. HIV Clin Trials. 2012;13(1):11-22.

40. Hutchinson AB, Farnham PG, Sansom SL, Yaylali E, Mermin JH. Costeffectiveness of frequent HIV testing of high-risk populations in the United States. J Acquir Immune Defic Syndr. 2016;71(3):323-30.

41. Peng S, Tafazzoli A, Dorman E, Rosenblatt L, Villasis-Keever A, Sorensen S. Cost-effectiveness of DTG + ABC/3TC versus EFV/TDF/FTC for first-line treatment of HIV-1 in the United States. J Med Econ. 2015;18(10):763-76.

42. Schackman BR, Fleishman JA, Su AE, et al. The lifetime medical cost savings from preventing HIV in the United States. Med Care. 2015;53(4):293-301.

43. Schackman BR, Haas DW, Park SS, Li XC, Freedberg K. Costeffectiveness of CYP2B6 genotyping to optimize efavirenz dosing in HIV clinical practice. Pharmacogenomics. 2015;16(18):2007-18.

44. Song DL, Altice FL, Copenhaver MM, Long EF. Cost-effectiveness analysis of brief and expanded evidence-based risk reduction interventions for HIV-infected people who inject drugs in the United States. PLoS One. 2015;10(2):e0116694

45. Sweet DE, Altice FL, Cohen CJ, Vandewalle B. Cost-effectiveness of single- versus generic multiple-tablet regimens for treatment of HIV-1 infection in the United States. PLoS One. 2016;11(1):e0147821.

46. Walensky RP, Sax PE, Nakamura YM, et al. Economic savings versus health losses: the cost-effectiveness of generic antiretroviral therapy in the United States. Ann Intern Med. 2013;158(2):84-92

47. Juusola JL, Brandeau ML, Owens DK, Bendavid E. The cost-effectiveness of preexposure prophylaxis for HIV prevention in the United States in men who have sex with men. Ann Intern Med. 2012;156(8):541-50. 
48. Dekoven M, Makin C, Slaff S, Marcus M, Maiese EM. Economic burden of HIV antiretroviral therapy adverse events in the United States. J Int Assoc Provid AIDS Care. 2016;15(1):66-76.

49. Korsnes JS, Goodwin BB, Murray M, Candrilli SD. Antiretroviral treatment switching and its association with economic outcomes and adverse treatment effects among commercially insured and Medicaid-enrolled patients with HIV in the United States. Ann Pharmacother. 2016;50(12):989-1000.

50. Ritchwood TD, Bishu KG, Egede LE. Trends in healthcare expenditure among people living with HIV/AIDS in the United States: evidence from 10 years of nationally representative data. Int J Equity Health. 2017;16(1):188.

51. Solem CT, Snedecor SJ, Khachatryan A, et al. Cost of treatment in a U.S. commercially insured, HIV-l-infected population. PLoS One. 2014:9(5):e98152.

52. Bryant L, Smith N, Keiser P. A model for reduced HIV-1 viral load monitoring in resource-limited settings. J Int Assoc Provid AIDS Care. 2013;12(1):67-71.

53. Holodniy M, Brown ST, Cameron DW, et al. Results of antiretroviral treatment interruption and intensification in advanced multi-drug resistant HIV infection from the OPTIMA trial. PLoS One. 2011;6:e14764.

54. Guaraldi G, Orlando G, Zona S, et al. Premature age-related comorbidities among HIV-infected persons compared with the general population. Clin Infect Dis. 2011;53(11):1120-26.

55. Deeks SG, Lewin SR, Havlir DV. The end of AIDS: HIV infection as a chronic disease. Lancet. 2013;382(9903):1525-33.

56. Tourret J, Deray G, Isnard-Bagnis C. Tenofovir effect on the kidneys of HIV-infected patients: a double-edged sword? J Am Soc Nephrol. 2013;24(10):151-27.

57. Grant P, Cottet A. Tenofovir and bone health. Curr Opin HIV AIDS. 2016;11(3):326-32

58. Ozieh MN, Bishu KG, Dismuke CE, Egede LE. Trends in healthcare expenditure in United States adults with chronic kidney disease: 2002-2011. BMC Health Serv Res. 2017;17:368.

59. Honeycutt AA, Segel JE, Zhuo X, Hoerger TJ, Imai K, Williams D. Medical costs of CKD in the Medicare population. J Am Soc Nephrol. 2013;24(9):1478-83.

60. Weaver J, Sajjan S, Lewiecki EM, Harris ST, Marvos P. Prevalence and cost of subsequent fractures among U.S. patients with an incident fracture. J Manag Care Spec Pharm. 2017;23(4):461-71. Available at: https://www.jmcp. org/doi/10.18553/jmcp.2017.23.4.461. Accessed January 9, 2020.

61. Barnett PG, Chow A, Joyce VR, et al. Determinants of the cost of health services used by veterans with HIV. Med Care. 2011;49(9):848-56

62. Gebo KA, Moore RD, Fleishman JA. The HIV Research Network: a unique opportunity for real time clinical utilization analysis in HIV. Hopkins HIV Rep. 2003;15(6):5-6

63. Bozzette SA, Berry SH, Duan N, et al. The care of HIV-infected adults in the United States. HIV Cost and Services Utilization Study Consortium. N Engl J Med. 1998;339(26):1897-904

64. Gebo KA, Fleishman JA, Conviser R, et al. Contemporary costs of HIV health care in the HAART era. AIDS (London, England). 2010;24(17):2705-15.

65. Long EF, Brandeau ML, Owens DK. The cost-effectiveness and population outcomes of expanded HIV screening and antiretroviral treatment in the United States. Ann Intern Med. 2010;153(12):778-89.

66. Krentz HB, Gill MJ. Cost of medical care for HIV-infected patients within a regional population from 1997 to 2006. HIV Med. 2008;9(9):721-30.

67. Centers for Medicare \& Medicaid Services. Medicare information for providers, partners and health care professionals. 2010. Available at: http:// www.cms.gov/home/medicare.asp. Accessed January 9, 2020.
68. Vergis EN, Mellors JW. Natural history of HIV-1 infection. Infect Dis Clin North Am. 2000;14:809-25.v-vi.

69. Schacker T, Collier AC, Hughes J, Shea T, Corey L. Clinical and epidemiologic features of primary HIV infection. Ann Intern Med. 1996;125:257-64.

70. Daar ES, Little S, Pitt J, et al. Diagnosis of primary HIV-1 infection. Los Angeles County Primary HIV Infection Recruitment Network. Ann Intern Med. 2001;134:25-29

71. Long EF, Brandeau ML, Owens DK. Potential population health outcomes and expenditures of HIV vaccination strategies in the United States. Vaccine. 2009;27:5402-10.

72. Hutchinson AB, Farnham PG, Dean HD, et al. The economic burden of HIV in the United States in the era of highly active antiretroviral therapy: evidence of continuing racial and ethnic differences. J Acquir Immune Defic Syndr. 2006;43:451-57.

73. Sanders GD, Bayoumi AM, Sundaram V, et al. Cost effectiveness of screening for HIV in the era of highly active antiretroviral therapy. N Engl J Med. 2005;352:570-85

74. University HealthSystems Consortium. PSN reported falls; Aggregated data 2008. Web seminar report. 2009. In: Hubbartt B, Davis S, Kautz D. Nurses' experiences with bed exit alarms may lead to ambivalence about their effectiveness (CE). Rehabil Nurs. 2011;36(5):196-69.

75. Andrulis DP, Weslowski VB, Hintz E, Spolarich AW. Comparisons of hospital care for patients with AIDS and other HIV-related conditions. JAMA. 1992;26718):2482-86

76. Healthcare Cost and Utilization Project (HCUP). 2007 and 2008 HCUP state inpatient data for CA, FL, MA, MD, NJ, WA. State inpatient databases (SID). Agency for Healthcare Research and Quality. Rockville, MD. Available at: http://www.hcup-us.ahrq.gov/db/state/siddbdocumentation.jsp. Accessed January 9, 2020

77. Schackman BR, Haas DW, Becker JE, et al. Cost-effectiveness analysis of UGTlAl genetic testing to inform antiretroviral prescribing in HIV disease. Antivir Ther. 2013;18(3):399-408

78. Centers for Medicare \& Medicaid Services. Clinical Laboratory Fee Schedule. 2009. Available at: http://www.cms.gov/Medicare/Medicare-Fee-forService-payment/ClinicalLabFeeSched/clinlab.html. Accessed January 9, 2020.

79. Agency for Healthcare Research and Quality. Medical Expenditure Panel Survey. 2009. Available at: http://meps.ahrq.gov/mepsweb/about_meps/survey_back.jsp. Accessed January 9, 2020.

80. Steiner C, Elixhauser A, Schnaier J. The healthcare cost and utilization project: an overview. Eff Clin Pract. 2002;5:143-51.

81. Healthcare Cost and Utilization Project (HCUP). Overview of the state inpatient databases (SID). Agency for Healthcare Research and Quality. Rockville, MD. 2011. Available at: https://www.hcup-us.ahrq.gov/sidoverview.jsp. Accessed January 9, 2020.

82. Centers for Medicare \& Medicaid Services. Physician Fee Schedule search. 2009. Available at: http://www.cms.hhs.gov/PFSlookup/02_ PFSSearch.asp. Accessed January 9, 2020.

83. Simpson K. Event data for South Carolina Medicaid patients from 2002 and 2003. Columbia: S.C. Budget and Control Board, Office of Research \& Statistics; 2005

84. Gebo KA, Fleishman JA, Conviser R, et al. Racial and gender disparities in receipt of highly active antiretroviral therapy persist in a multistate sample of HIV patients in 2001. J Acquir Immune Defic Syndr. 2005;38(1):96-103

85. Bamezai A, Melnick G, Nawathe A. The cost of an emergency department visit and its relationship to emergency department volume. Ann Emerg Med. 2005;45(4):483-89. 


\section{APPENDIX A Search Strategy}

\#

1 HIV[MeSH Terms]

2 HIV Infections[MeSH Terms]

3 (HIV Infections[Title/Abstract] OR HIV? ${ }^{*}[$ Title/Abstract] OR HIV?2*[Title/Abstract] OR HIV infect*[Title/Abstract] OR human immuno?deficiency virus[Title/Abstract] OR human immune?deficiency virus[Title/Abstract])

4 (human immun*[Title/Abstract]) AND deficiency virus[Title/Abstract] Title/Abstract] OR acquired immune deficiency[Title/Abstract])

6 (acquired immun*[Title/Abstract]) AND deficiency syndrome[Title/Abstract]

7 \#1 OR \#2 OR \#3 OR \#4 OR \#5 OR \#6

8 "economics, medical"[MeSH Terms]

9 (economics) OR economics[MeSH Terms]

10 "economic evaluation"

11 (((health care cost[MeSH Terms]) OR health care costs[MeSH Terms]) OR (costs and cost analysis[MeSH Terms])) OR costs[MeSH Terms]

12 "health care utilization"

13 "drug costs"[MeSH Terms]

14

15

5

16

17

17

29

(resource*[Title/Abstract] OR healthcare[Title/Abstract] OR service*[Title/Abstract])

(use*[Title/Abstract] OR utilis*[Title/Abstract] OR utilize*[Title/Abstract] OR consume*[Title/Abstract] OR consuming[Title/ Abstract] OR consumption*[Title/Abstract])

(((“cost-benefit analysis"[MeSH Terms] OR cost effectiveness[Text Word]) OR cost-effectiveness[Title/Abstract] OR CEA[Title/ Abstract]))

Cost[Title/Abstract] or costs[Title/Abstract] or costing[Title/Abstract]

cost utility*[Title/Abstract] OR cost benefit*[Title/Abstract] OR cost minimi*[Title/Abstract]

economic*[Title/Abstract] OR pharmacoeconomic*[Title/Abstract]

expenditure*[Title/Abstract] NOT energy[Title/Abstract]

value[Title/Abstract] AND money[Title/Abstract]

Budget*[Title/Abstract]

\#8 OR \#9 OR \#10 OR \#11 OR \#12 OR \#13 OR \#14 OR \#15 OR \#16 OR \#17 OR \#18 OR \#19 OR \#20 OR \#21 OR \#22

((energy cost[Title/Abstract] OR oxygen cost[Title/Abstract]))

metabolic cost[Title/Abstract]

((energy expenditure[Title/Abstract] OR oxygen expenditure[Title/Abstract]))

\#24 OR \#25 OR \#26

\#23 NOT \#27

\#7 AND \#28

(((((((case report) OR case study) OR letter) OR editorial) OR case reports[Publication Type]) OR letter[Publication Type])

OR editorial[Publication Type])

\#29 NOT \#30

"United States"[Title/Abstract] OR America[Title/Abstract] OR USA[Title/Abstract]

\#31 AND \#32

\#33 Date: 2012-01-01 to present

\#34 Language: English 


\section{APPENDIX B PRISMA Diagram}

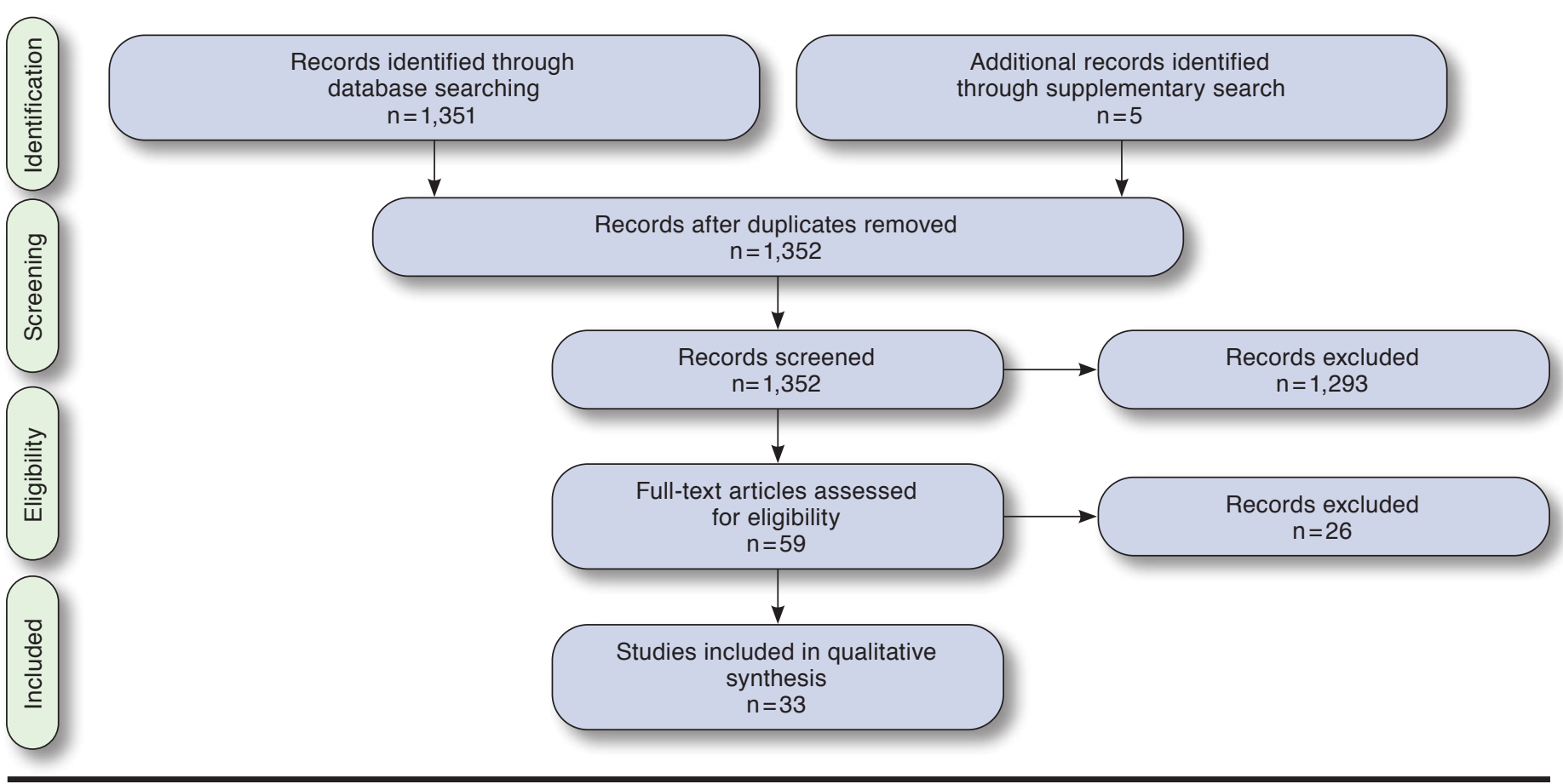

